\title{
PENERAPAN TEORI PERKEMBANGAN MENTAL PIAGET PADA KONSEP KEKEKALAN PANJANG
}

\author{
Oleh : \\ Idrus Alhaddad \\ Program Studi Pendidikan Matematika FKIP Universitas Khairun Ternate \\ e-mail: Idrus_ekal@yahoo.co.id
}

\begin{abstract}
Abstrak
Menurut teori perkembangan mental dari Piaget, ada 4 tahapan perkembangan kognitif pada anak, yaitu: 1) Tahap sensori motor, yaitu dari lahir sampai usia sekitar 2 tahun; 2) Tahap pre operasi, yaitu dari usia sekitar 2 tahun sampai sekitar 7 tahun; 3) Tahap operasi konkrit, yaitu dari usia sekitar 7 tahun sampai sekitar 11-12 tahun; dan 4) Tahap operasi formal, yaitu dari usia dari sekitar 11 tahun sampai dewasa.

Setiap tahapan perkembangan mental mempunyai sifat atau ciri khas masing-masing. Salah satu ciri yang dimunculkan pada tahap operasi kongkrit diantaranya yaitu bahwa pada tahap ini anak sudah mulai memahami konsep kekekalan. Diantaranya konsep kekekalan panjang (7 - 8 tahun). Tentu saja hal itu ditujukan untuk anak-anak luar negeri dimana Jean Piaget melakukan penelitian, yaitu di Negara Swiss.

Pertanyaannya adalah apakah tahapan perkembangan anak berlaku juga pada anak di negara kita. Hasil penelitian yang kami lakukan menunjukkan bahwa, ada anak yang sesuai dengan usianya berada pada tahapan operasi kongkrit ternyata belum memahami konsep kekekalan panjang.
\end{abstract}

Kata kunci : Teori perkembangan mental, Konsep kekekalan Panjang

\section{Pendahuluan}

Dalam proses pembelajaran matematika, siswa perlu dibiasakan untuk memecahkan masalah, menemukan sesuatu yang berguna bagi dirinya, dan bekerja dengan ide-ide.Guru tidak akan mampu memberikan semua pengetahuan pada siswa. Siswa harus dapat mengkonstruksikan pengetahuan dibenak mereka sendiri. Ini sesuai dengan esensi dari teori konstruktivisme bahwa siswa harus menemukan dan mentransformasikan suatu informasi kompleks ke situasi lain, dan apabila dikehendaki, informasi itu menjadi milik mereka sendiri.

Salah satu tokoh pencetus kontruktivisme adalah Jean Piaget. Dari hasil penelitianya itu timbullah teori belajar yang biasa disebut teori perkembangan mental atau teori kognitif. Teori ini menetapkan ragam dari tahap-tahap 
perkembangan intelektual manusia dari lahir sampai dewasa serta ciri-cirinya dari setiap tahap itu.

Menurut teori perkembangan mental Piaget, ada 4 tahapan perkembangan kognitif pada anak, yaitu: 1) Tahap sensori motor (sensori-motor stage), yaitu dari lahir sampai usia sekitar 2 tahun; 2) Tahap pre operasi (pre operational stage), yaitu dari usia sekitar 2 tahun sampai sekitar 7 tahun; 3) Tahap operasi konkrit (concrete operational stage), yaitu dari usia sekitar 7 tahun sampai sekitar 11-12 tahun; dan 4) Tahap operasi formal (formal operational stage), yaitu dari usia dari sekitar 11 tahun sampai dewasa.

Setiap tahapan perkembangan mental mempunyai sifat atau ciri khas masingmasing yang dimunculkan anak yang berbeda-beda. Salah satu ciri yang dimunculkan pada tahap operasi kongkrit (concrete operational stage) diantaranya yaitu pada tahap ini anak sudah mulai memahami konsep kekekalan. Sebagaimana yang diungkapkan Ruseffendi (2006:147) pada tahap operasi kongkrit anak mulai memahami konsep kekekalan bilangan (6 - 7 tahun), konsep kekekalan materi atau zat ( 7 - 8 tahun), konsep kekekalan panjang (7 - 8 tahun), konsep kekekalan luas (8 - 9 tahun), konsep kekekalan berat ( 9 - 10 tahun), bahkan pada akhir tahap ini, anak sudah dapat memahami konsep kekekalan isi (14 - 15 tahun). Tentu saja hal itu ditujukan untuk anakanak luar negeri dimana Jean Piaget melakukan penelitian, yaitu di Negara Swiss.

Pertanyaannya adalah bagaimana teori tahapan perkembangan anak yang disusun oleh Piaget itu berlaku juga pada anak yang ada di negara kita, terutama di lingkungan tempat tinggal kita. Untuk menjawab pertanyaan tersebut, perlu dilakukan suatu penelitian. Penelitian ini memfokuskan pada pemahaman konsep kekekalan panjang yang dimiliki anak-anak yang ada di sekitar kita khususnya, dan anak-anak Indonesia pada umumnya.

Berdasarkan uraian latar belakang di atas, maka pertanyaan penelitian yang diajukan dalam penelitian ini adalah: "Bagaimana kondisi perkembangan mental anak terkait pemahaman konsep kekekalan panjang, apakah anak-anak pada usia 7 - 8 tahun sudah memahami konsep kekekalan panjang?"

Tujuan penelitian ini yaitu untuk mengetahui kondisi perkembangan mental anak terkait pemahaman konsep kekekalan panjang, apakah anak-anak Indonesia pada usia 7 - 8 tahun sudah memahami konsep kekekalan panjang.

Hasil penelitian ini diharapkan dapat bermanfaat sebagai studi pendahuluan dan bahan kajian untuk penelitian lebih lanjut, referensi bagi para guru di 
sekolah dasar, dan para orang tua dalam menerapkan pola pendidikan yang efektif untuk anak-anak sesuai dengan kondisi perkembangan mentalnya.

\section{A. Hakekat Matematika}

Apakah matematika itu? sampai saat ini belum ada definisi yang menjadi kesepakatan dari para matematikawan tentang satu-satunya definisi matematika. Para matematikawan saling berbeda dalam mendefinisikan matematika,

Herman Hudojo (1988: 3) menyatakan bahwa matematika berkenaan dengan ide-ide/ konsep-konsep yang abstrak yang tersusun secara hirarkis dan penalarannya deduktif. Sejalan dengan pandangan tersebut, Sujono (1988: 5) mengemukakan beberapa pengertian matematika. Diantaranya, matematika diartikan sebagai cabang ilmu pengetahuan yang eksak dan terorganisasi secara sistematik. Selain itu, matematika merupakan ilmu pengetahuan tentang penalaran yang logik dan masalah yang berhubungan dengan bilangan. Bahkan dia mengartikan matematika sebagai ilmu bantu dalam mengiterpretasikan berbagai ide dan kesimpulan. Ruseffendi (2006: 261) menyatakan,

Matematika terdiri dari 4 wawasan yang luas ialah aritmatika, aljabar, geometri dan analisis. Dimana dalam aritmatika mencakup antara lain: teori bilangan dan statistika. Selain itu matematika adalah ratunya ilmu (Mathematics is the Queen of the sciences), maksudnya antara lain matematika tidak bergantung kepada bidang studi lain; bahasa, dan agar dapat dipahami orang dengan tepat kita harus menggunakan simbol dan istilah yang cermat yang disepakati secara bersama; ilmu deduktif yang tidak menerima generalisasi yang didasarkan kepada observasi (induktif) tetapi generalisasi yang didasarkan kepada pembuktian secara deduktif; ilmu tentang pola keteraturan; ilmu tentang struktur yang terorganisasi mulai dari unsur yang tidak didefinisikan, ke unsur yang didefinisikan ke aksioma atau postulat dan akhirnya ke dalil, dan matematika adalah pelayan ilmu

Meskipun terdapat beraneka ragam definisi matematika, namun jika diperhatikan secara seksama, dapat terlihat adanya ciri-ciri khusus yang dapat merangkum pengertian matematika secara umum. Soedjadi (2000: 13) mengemukakan beberapa ciri khusus dari matematika adalah :

1. memiliki objek kajian abstrak,

2. bertumpu pada kesepakatan,

3. berpola berpikir deduktif,

4. memiliki simbol yang kosong dari arti, 
5. memperhatikan semesta pembicaraan,

6. konsisten dalam sistemnya.

Berdasarkan uraian yang telah dikemukakan dapat dikatakan bahwa hakekat matematika adalah kumpulan ide-ide yang bersifat abstrak, struktur-struktur dan hubungannya diatur menurut aturan logis dan berdasarkan pada pola pikir deduktif.

\section{B. Jean Piaget dengan Teori Perkembangan Mentalnya}

Jean Piaget lahir pada tanggal 9 Agustus 1896 di Neuchatel, Swiss. Piaget mengembangkan teori perkembangan kognitif yang cukup dominan selama beberapa dekade. Dalam teorinya Piaget membahas pandangannya tentang bagaimana anak belajar. Ini merupakan suatu pandangan konstruktivisme.

Pada Pandangan konstruktivisme, pengetahuan tumbuh dan berkembang melalui pengalaman. Pemahaman berkembang semakin dalam dan semakin kuat apabila selalu diuji dengan pengalaman baru. Manusia memiliki struktur pengetahuan dalam otaknya, seperti kotak-kotak yang masing-masing berisi informasi bermakna yang berbeda-beda. Pengalaman yang sama bagi beberapa orang akan dimaknai berbeda-beda oleh masing-masing individu dan disimpan dalam kotak yang berbeda. Setiap pengalaman baru dihubungkan dengan kotak-kotak (struktur pengetahuan) dalam otak manusia. Struktur pengetahuan dikembangkan dalam otak manusia melalui dua cara, yaitu asimilasi dan akomodasi. Asimilasi, maksudnya struktur pengetahuan baru dibuat atau dibangun atas dasar struktur pengetahuan yang sudah ada. Akomodasi, maksudnya struktur pengetahuan yang sudah ada dimodifikasi untuk menampung dan menyesuaikan dengan hadirnya pengalaman baru.

Menurut Piaget dalam Ruseffendi (2006 : 133) ada tiga dalil pokok dalam perkembangan mental manusia, yaitu :

1. Perkembangan intelektual terjadi melalui tahap-tahap beruntun yang selalu terjadi dengan urutan yang sama.

2. Tahap-tahap itu didefinisikan sebagai kluster dari operasi-operasi mental yang menunjukkan adanya tingkah laku intelektual.

3. Gerak melalui tahap-tahap itu dilengkapkan oleh adanya keseimbangan (ekuilibration) proses pengembangan yang menguraikan tentang in interaksi antara pengalaman (asimilasi) dan struktur kognitif yang timbul (akomodasi).

Disamping itu ada empat konsep dasar Piaget yang dapat diaplikasikan pada pendidikan matematika, yang berimplikasi pada organisasi lingkungan 
pendidikan, isi kurikulum dan urut-urutannya, metode mengajar, dan evaluasi. Keempat konsep dasar tersebut adalah: (1) Skemata, (2) asimilasi, (3) akomodasi, dan (4) ekuilibrium (Senduk, 1985: 10-16).

Menurut Piaget tahap perkembangan intelektual anak secara kronologis terjadi 4 tahap. Urutan tahap-tahap ini tetap bagi setiap orang, akan tetapi usia kronologis memasuki setiap tahap bervariasi pada setiap anak. Keempat tahap dimaksud adalah sebagai berikut: 1) Tahap sensori motor,dari lahir sampai usia sekitar 2 tahun; 2) Tahap pre operasi, dari usia sekitar 2 tahun sampai sekitar 7 tahun; 3) Tahap operasi konkrit, dari usia sekitar 7 tahun sampai sekitar 11 - 12 tahun; dan 4) Tahap operasi formal, dari usia sekitar 11 tahun sampai dewasa. Sebaran umur setiap tahap itu adalah rata-rata (sekitar) dan mungkin terdapat perbedaan antara masyarakat yang satu dengan masyarakat yang lain dan antara anak yang satu dengan anak yang lain dalam suatu masyarakat. Ada kemungkinan memang teori itu hanya berlaku untuk anakanak barat, dimana Piaget melakukan penelitian. Adapun penjelasan selengkapnya mengenai tahapan-tahapan perkembangan mental Piaget dalam Ruseffendi (2006) adalah sebagai berikut:

\section{Tahap sensori motorik (sensori motor stage)}

Tahap ini merupakan tahap perkembangan yang dialami semenjak lahir hingga usia sekitar 2 tahun. Untuk anak pada tahap ini, yang utama adalah berpengalaman melalui berbuat dan sensori. Sedangkan berpikirnya melalui perbuatan (tindakan), gerak, dan reaksi yang spontan. Pada tahap ini, intelegensi anak lebih didasarkan pada tindakan terhadap lingkungannya, seperti melihat, meraba, menjamak, mendengar, membau dan lain-lain.

Mekanisme perkembangan sensorimotor ini menggunakan proses asimilasi dan akomodasi. Tahap-tahap perkembangan kognitif anak dikembangkan dengan perlahan-lahan melalui proses asimilasi dan akomodasi terhadap skema-skema anak karena adanya masukan, rangsangan, atau kontak dengan pengalaman dan situasi yang baru.

Adapun ciri-ciri tahap sensori motor adalah sebagai berikut:

a. Anak belajar mengembangkan dan menyelaraskan jasmaninya dengan perbuatan mentalnya menjadi tindakan-tindakan atau perbuatan yang teratur dan pasti. Ia belajar mengkoordinasikan akal dan geraknya. kegiatan penyelarasan perbuatan gerak fisik dan perbuatan mentalnya itu disebut "schemata".

b. Anak berpikir melalui perbuatan dan gerak.

c. Perkembangan yang terjadi pada tahap ini adalah dari gerak refleks ngemot dan gerak mata sampai pada kemampuan untuk makan, melihat, memegang, berjalan, dan berbicara. 
d. Pada akhir tahap ini, anak belajar mengaitkan simbol benda dengan benda konkretnya, hanya masih kesulitan. Misalnya, ia mengaitkan penglihatan mentalnya dengan penglihatan real dari benda yang disembunyikan. Pada akhir tahap ini. Anak belajar bahwa benda yang disembunyikan dari penglihatan itu tidak menghilang terus, sebagaimana yang sebelumnya ia kira.

e. Pada akhir tahap ini pula, anak mulai melakukan percobaan coba-coba berkenalan dengan benda-benda konkret (dengan menyusunnya, mengutakatik, dan lain-lain).

\section{Tahap pre operasi (pre operational stage)}

Tahap kedua dari teori perkembangan mental manusia dari Piaget adalah tahap pre operasi. Istilah "operasi" di sini adalah suatu proses berfikir logik, dan merupakan aktivitas sensorimotor. Dalam tahap ini anak sangat egosentris, mereka sulit menerima pendapat orang lain. Anak percaya bahwa apa yang mereka pikirkan dan alami juga menjadi pikiran dan pengalaman orang lain. Mereka percaya bahwa benda yang tidak bernyawa mempunyai sifat bernyawa. Tahap ini adalah tahap dimana anak mulai melakukan persiapan dalam pengorganisasian operasi konkret. Tahap perkembangan ini dapat dibagi ke dalam dua bagian. Pertama, tahap berpikir pre konseptual (sekitar usia 2 - 4 tahun), dimana representasi suatu objek dinyatakan dengan bahasa, gambar dan permainan khayalan. Kedua, tahap berpikir intuitif (sekitar usia $4-7$ tahun), dimana pada tahap ini representasi suatu objek didasarkan pada persepsi pengalaman sendiri, tidak kepada penalaran.

Adapun ciri-ciri tahap perkembangan pre operasi adalah sebagai berikut:

a. Sebaran umur sekitar 2 - 7 tahun; tahap berpikir pre konseptual sekitar 2 4 tahun dan tahap berpikir intuitif sekitar $4-7$ tahun.

b. Bila dibandingkan, pada tahap ini, anak berpikir internal (penghayatan ke dalam) sedangkan pada tahap sensori motor dengan gerak atau perbuatan. Anak pada tahap pre konseptual memungkinkan representasi sesuatu itu dengan bahasa, gambar, dan permainan khayalan. Penilaian dan pertimbangan anak pada tahap berpikir intuitif didasarkan pada persepsi pengalaman sendiri, belum pada penalaran.

c. Anak mengaitkan pengalaman yang ada pada dunia luar dengan pengalaman pribadinya. Anak mengira bahwa cara berpikirnya dan pengalamannya dimiliki pula oleh orang lain. Misalnya, jika ia melihat sebuah gambar terbalik dari arah sisi meja yang satu, akan mengira temannya yang berhadapan dengan dia di sisi lain dari meja itu, akan melihat gambar tersebut secara terbalik pula. Oleh karena itu, kita menemukan bahwa anakanak pada tahap ini sangat egois, tidak membenarkan barang mainannya, makanannya, dan lain-lainnya, dijamah oleh anak lain. 
d. Anak mengira bahwa benda-benda tiruan itu memiliki sifat-sifat benda yang sebenarnya. Contoh untuk ini misalnya perlakuan anak terhadap bonekanya, seperti perlakuannya terhadap anak yang sebenarnya (mengajak bicara, mengasih makan dan minum, menyuruh tidur, dan lain-lain).

e. Pada tahap ini, anak tidak dapat membedakan antara kejadian-kejadian yang sebenarnya (fakta) dengan khayalannya (fantasi). Oleh karena itu, jika dia berdusta "berdustanya" itu bukan karena moralnya jelek, tetapi karena kelemahannya. Ia tidak dapat membedakan mana fakta dan mana fantasi.

f. Anak berpendapat bahwa benda-benda akan berbeda jika kelihatannya berbeda.

g. Anak pada tahap ini memiliki kesukaran membalikkan dan mengulang pemikiran (perbuatan). Anak tidak dapat atau sukar memahami apa yang akan terjadi jika air yang ada dalam bejana sebelah kanan ditumpahkan ke dalam bejana sebelah kiri. Anak pada tahap ini belum dapat melakukan operasi invers.

h. Anak masih kesulitan untuk memikirkan dua aspek atau lebih dari suatu benda secara serempak. Misalnya ia akan kesulitan jika ia diminta untuk mengumpulkan kelereng besar dan berwarna hijau misalnya. Demikian pula ia akan kesulitan jika harus memahami bahwa himpunan laki-laki dan himpunan orang dewasa itu ada irisannya.

i. Anak belum berpikir induktif maupun deduktif, melainkan transitif (dari khusus ke khusus).

j. Anak mampu memanipulasi benda-benda konkret.

k. Anak mulai dapat membilang dengan menggunakan benda konkret, misalkan jari tangannya.

1. Pada akhir tahap ini, anak dapat memberikan alasan atas keyakinannya, dapat mengelompokkan benda-benda berdasarkan satu sifat khusus yang sederhana, dan mulai dapat memperoleh konsep yang sebenarnya.

m. Anak belum dapat memahami korespondensi satu-satu untuk memahami banyaknya (kesamaan dan ketidaksamaan). Anak mengalami kesulitan untuk memahami bahwa bilangan kardinal dari himpunan bilangan asli adalah sama banyak dengan bilangan kardinal dari himpunan bilangan asli genap.

n. Anak sulit memahami konsep ketakhinggaan dan pembagian tak terbatas dari sebuah ruas garis atas ruas garis-ruas garis yang lebih kecil panjangnya.

\section{Tahap operasi kongkrit (concrete operational stage)}

Tahap ini merupakan tahap anak-anak sekolah dasar pada umumnya. Pada tahap ini, anak dapat memahami operasi (logis) dengan bantuan benda-benda kongkrit. Yang dimaksud operasi dengan bantuan benda-benda kongkrit disini adalah tindakan atau perbuatan mental mengenai kenyataan dalam kehidupan nyata. Anak tidak perlu selalu dengan bantuan benda-benda kongkrit ketika 
melakukan operasi. Akan tetapi ada kemungkinan, anak-anak masih kesulitan membuat generalisasi verbal dari contoh-contoh yang serupa.

Oleh karena itu, anak-anak pada tahap ini dapat dikelompokkan ke dalam taraf berpikir kongkrit yaitu selalu memerlukan bantuan benda-benda kongkrit, atau taraf berpikir semi kongkrit, artinya dapat mengerti jika dibantu dengan gambar benda kongkrit. Dapat pula dikatakan taraf berpikir semi abstrak, yaitu dapat mengerti dengan bantuan diagram, torus, atau sejenisnya. Serta dapat pula dikatakan berada pada taraf berpikir abstrak, yaitu dapat mengerti tanpa bantuan benda-benda real, gambar ataupun diagramnya.

Adapun ciri-ciri anak tahap operasi kongkrit adalah sebagai berikut:

a. Sebaran umur dari sekitar 7 - 11 atau 12 tahun, kadang-kadang lebih.

b. Pada permulaan tahap ini, egoismenya mulai berkurang. Anak mulai bersedia bermain dengan teman-temannya, tukar-menukar mainan, dan lain-lainnya.

c. Dapat mengelompokkan benda-benda yang mempunyai beberapa karakteristik ke dalam himpunan dan himpunan bagian dengan karakteristik khusus dan dapat melihat beberapa karakteristik suatu benda secara serentak.

d. Mampu berkecimpung dalam hubungan kompleks antara kelompokkelompok, dapat membalikkan operasi dan prosedur, serta dapat melihat 'langkah (keadaan) antara' dari suatu perubahan. Misalnya, keadaan antara ayahnya pergi dan pulang kantor, langkah antara matahari terbit dan terbenam, dan lain-lain.

e. Jika pada tahap pre operasional anak belum memahami konsep kekekalan, tetapi pada tahap ini sudah anak sudah memahami konsep kekekalan. Konsep kekekalan bilangan (6 - 7 tahun); kekekalan materi (7 - 8 tahun); kekekalan panjang (7 - 8 tahun); kekekalan luas (8 - 9 tahun); dan konsep kekekalan berat ( 9 - 10 tahun). Bahkan pada akhir tahap ini, anak sudah dapat memahami konsep kekekalan isi (14 - 15 tahun kadang-kadang mulai pada usia 11 tahun).

f. Mampu melihat sudut pandangan orang lain. Pada tahap ini, anak belajar membedakan antara perbuatan salah yang disengaja dengan kesalahan yang tidak disengaja. Bagi anak pada tahap ini kucing itu dinamai (disebut) kucing karena binatang itu adalah kucing, bukan karena pemberian nama oleh manusia.

g. Dapat menyelesaikan soal seperti $\square+3=9$

h. Dapat menggunakan tambang panjang 3, 4, dan $5 \mathrm{~m}$ dan bilangan Pythagoras lainnya untuk membuat segi tiga siku-siku.

i. Anak-anak pada tahap ini senang membuat benda bentukan, memanipulasi benda, dan membuat alat mekanis. 
j. Pada akhir tahap ini, anak dapat memberikan alasan deduktif dan induktif, tetapi masih banyak memandang contoh berurutan dari suatu prinsip umum sebagai hal-hal yang tidak berhubungan, misalnya dalam langkah-langkah terurut pada pembuktian induksi matematika.

k. Berpikirnya lebih dinamis, berpikir ke depan - ke belakang dalam suatu struktur atau konteks.

1. Masih mengalami kesulitan untuk menjelaskan peribahasa dan tidak mampu melihat arti yang tersembunyi. Tetapi ia mulai dapat memahami orang yang membadut (berjenaka).

m. Anak jarang dapat membuat definisi deskriptif yang tepat, meskipun demikian ia dapat mengingat-ingat definisi buatan orang lain dan mengatakan kembali apa yang dihapalkannya.

n. Masih kesulitan memahami abstraksi verbal. Anak mampu melakukan operasi kompleks seperti kebalikan, substitusi, gabungan dan irisan, dan pengurutan dari benda-benda kongkrit, tetapi mungkin tidak mampu menyelesaikan operasi-operasi ini dengan simbol-simbol verbal. Kekuatan penilaian (judgement) dan memberi alasan secara logis belum berkembang dengan baik dan anak jarang dapat menyelesaikan soal cerita yang berhubungan dengan hukum transitif.

o. Tahap ini disebut tahap operasi kongkrit sebab anak-anak usia antara 7 - 12 tahun mengalami kesulitan dalam menerapkan proses intelektual formal ke simbol-simbol verbal dan ide-ide abstrak. Meskipun demikian anak pada usia 12 tahun sangat mahir menggunakan kepandaiannya untuk memanipulasi benda-benda kongkrit.

\section{Tahap operasi formal (formal operational stage)}

Tahap operasi formal merupakan tahap terakhir dalam perkembangan kognitif menurut Piaget. Pada tahap ini, seorang remaja sudah dapat berpikir logis, berpikir dengan pemikiran teoritis formal berdasarkan proposisi-proposisi dan hipotesis, dapat mengambil kesimpulan lepas dari apa yang dapat diamati saat itu, dan cara berpikir yang abstrak mulai dimengerti.

Adapun ciri-ciri tahap operasi formal adalah sebagai berikut:

a. Berusia sekitar 11 - 12 tahun ke atas (disebut juga anak dewasa).

b. Tidak memerlukan perantara operasi konkret lagi untuk menyajikan abstraksi mental secara verbal.

c. Dapat mempertimbangkan banyak pandangan sekaligus dan dapat memandang perbuatannya secara objektif dan merefleksikan proses berpikirnya.

d. Mulai belajar merumuskan hipotesis (perkiraan) sebelum ia berbuat. Misalnya ia dapat memperkirakan apa yang akan terjadi pada waktu menggoreng bila ia memasukkan daging ayam berair ke dalam katel 
berminyak yang sangat panas. Percobaan dilakukan untuk membuktikan hipotesisnya.

e. Dapat merumuskan dalil/teori, menggeneralisasikan hipotesis, dan mengetes bermacam hipotesis.

f. Dapat menghayati derajat kebaikan dan kesalahan dan dapat memandang definisi, aturan, dan dalil dalam konteks yang benar dan objektif.

g. Dapat berpikir deduktif dan induktif, dapat memberikan alasan-alasan dari kombinasi pernyataan dengan menggunakan konjungsi, disjungsi, negasi, dan implikasi, serta memahami induksi matematika.

h. Anak dapat memahami dan menggunakan konteks kompleks seperti permutasi, kombinasi, perbandingan (proposisi), korelasi dan probabilitas, dan dapat menggambarkan besar tak hingga dan kecil tak hingga

Operasi formal pada tahap perkembangan mental ini tidak berhubungan dengan ada atau tidaknya benda-benda kongkrit, tetapi berhubungan dengan tipe berpikir. Apakah situasinya disertai oleh benda-benda kongkrit atau tidak, tidak menjadi masalah.

\section{Konsep Kekekalan Panjang}

Menurut Piaget konsep kekekalan panjang belum dimiliki oleh anak-anak pada tahap pre operasi, akan tetapi sudah dimiliki oleh anak-anak pada tahap operasi kongkrit (Ruseffendi, 2006). Misalnya, percobaan pada dua utas tali yang pada mulanya sama panjang. Kemudian diubah bentuknya menjadi berbeda. Seperti terlihat pada gambar berikut:

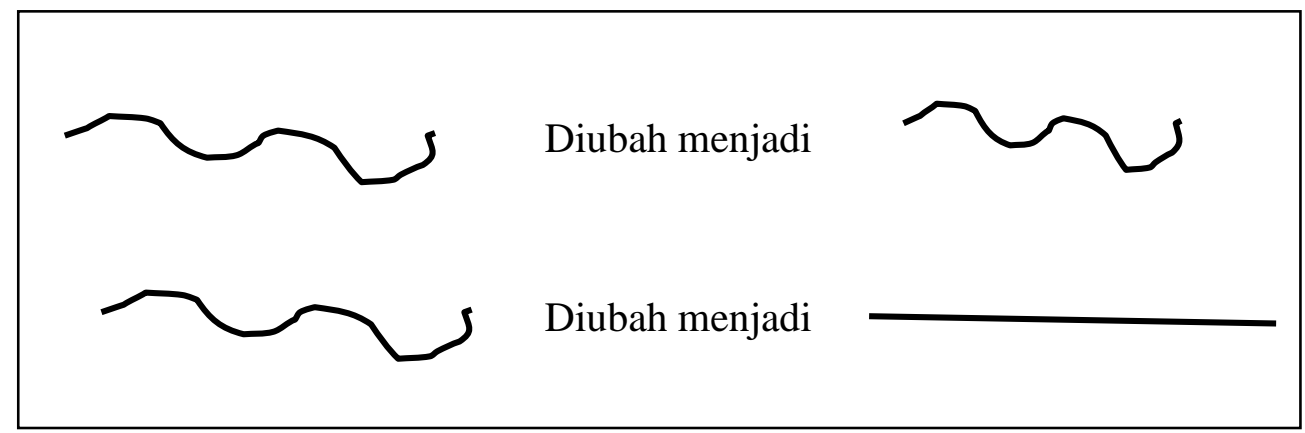

Gambar 1. Keadaan tali sebelum dan sesudah diubah

Anak pada tahap ini juga berpendapat bahwa tali yang ada disebelah kiri itu masing-masing tidak sama panjang dengan satu tali disebelah kanannya meskipun ia menyaksikan diubahnya. Hal ini dikarenakan ia belum memahami konsep kekekalan panjang. 


\section{Metode Penelitian}

Penelitian ini dilaksanakan pada hari Kamis, tanggal 1 Desember 2011di RT 2 / RW 3, Kelurahan Geger Kalong, Kecamatan Sukasari Kota Bandung Propinsi Jawa Barat.

Yang menjadi Subjek dalam penelitian hanya dua orang anak, Anak Pertama (A), Umur 8 tahun 6 bulan, Kelas III SD Sukarasa 34 Bandung. Anak Kedua (B), Umur 9 tahun 7 bulan, Kelas V SD Sukarasa 34 Bandung.

Alat dan bahan yang digunakan dalam penelitian ini adalah seutas tali, mistar dan sebuah gunting.

Percobaan dilakukan dengan langkah-langkah sebagai berikut:

1. Anak diperlihatkan pada seutas tali yang panjang. Kemudian tali tersebut dipotong dihadapan anak dengan ukuran yang sama.

2. Kemudian peneliti menanyakan pertanyaan pertama yaitu: Perhatikan kedua tali ini, apakah panjangnya sama atau berbeda?'.

3. Selanjutnya dari kedua tali tersebut, salah satunya dikencangkan (ditarik) sehingga menjadi lurus sedangkan yang lainnya dibiarkan saja. Hal ini dilakukan di depan anak.

4. Setelah tali yang satu dikencangkan, kemudian peneliti kembali menanyakan pertanyaan kedua yaitu: 'Sekarang perhatikan kedua tali ini, apakah panjang kedua tali tersebut masih sama panjang atau sudah berbeda? Yang Mana?, Mengapa?

Percobaan yang dilakukan terhadap kedua anak tersebut, dilaksanakan secara terpisah. Hal ini dimaksudkan agar jawaban yang diberikan tidak saling mempengaruhi.

Metode yang digunakan adalah eksperimen dan dilanjutkan dengan wawancara kepada kedua anak tersebut. Untuk memperoleh data tambahan, kedua orang tua anak tersebut juga diwawancarai.

\section{Hasil dan Pembahasan}

\section{A. Hasil Penelitian}

Hasil yang diperoleh dari percobaan yang telah dilakukan terhadap kedua anak tersebut dapat diuraikan sebagai berikut. 


\section{Anak Pertama (A)}

Pada anak pertama (A) untuk pertanyaan pertama: "Apakah panjangnya sama atau berbeda?", dia menjawab "Sama panjang". Hal ini karena dia melihat waktu peneliti memotong kedua tali tersebut. Namun pada pertanyaan kedua "Sekarang perhatikan kedua tali ini, apakah kedua tali tersebut masih sama panjang?",dia menjawab: "Tidak sama" sambil menunjuk mana yang lebih panjang.

\section{Anak Kedua (B)}

Pada anak kedua (B) dilakukan prosedur yang sama namun pada waktu yang berbeda. Agar jawaban dari tiap anak tidak saling mempengaruhi. Untuk pertanyaan pertama: “Apakah panjangnya sama atau berbeda?", dia menjawab "Sama panjang". Pada pertanyaan kedua "Sekarang perhatikan kedua tali ini, apakah kedua tali tersebut masih sama panjang?",dia menjawab: "Sama panjang" untuk menelusuri jawaban tersebut, peneliti melanjutkan dengan pertanyaan berikut: "Mengapa masih sama panjang?"Dia menjawab: Karena waktu digunting sama panjang" Peneliti masih mengejar dengan pertanyaan lanjutan: "Tapi tali yang ini sudah dikencangkan, sedangkan yang satunya tidak". Anak (B) menjawab: "Karena tidak digunting lagi maka panjangnya tetap sama"

\section{B. Pembahasan}

Dalam menguraikan pembahasan ini, peneliti mengklasifikasi berdasarkan pertanyaan kemudian subjek penelitian

\section{B.1. Pertanyaan pertama: Apakah panjangnya sama atau berbeda?}

Dalam menjawab pertanyaan ini, keduanya menjawab sama panjang. Hal ini karena mereka melihat waktu tali diukur dan dopotong. Tidak ada perbedaan jawaban diantara kedua anak tersebut. Hal ini sesuai dengan kenyataan sebenarnya, bahwa kedua tali sama panjang.

\section{B.2. Pertanyaan kedua: Apakah panjang kedua tali tersebut masih sama panjang?}

Dalam menjawab pertanyaan tersebut, diperoleh jawaban yang berbeda dari kedua anak tersebut. Selanjutnya dalam menelusuri jawaban dari kedua anak tersebut, peneliti mengklasifikasi berdasarkan subjek penelitian.

Anak Pertama (A) menjawab tidak sama panjang. Setelah ditanyakan kembali: Mengapa? Diperoleh jawaban bahwa anak ini hanya melihat letak dari ujung tali. Karena tali yang satu dikencangkan maka ujungnya lebih jauh dari tali yang lain. Hal ini menunjukkan bahwa anak ini hanya melihat dari apa yang nampak, tanpa mengingat kondisi awal tali tersebut. 
Dari jawaban tersebut, dapat dikatakan bahwa anak belum memahami konsep kekekalan panjang. Padahal dilihat dari usianya 8 tahun 6 bulan, seharusnya sudah masuk dalam tahapan operasi kongkrit. Dimana pada tahap operasi kongkrit, anak seharusnya sudah memahami konsep kekekalan panjang. Hal ini berarti bahwa ternyata ada anak yang belum memahami konsep kekekalan panjang, meskipun dilihat dari usia, seharusnya sudah berada pada tahap operasi kongkrit.

Anak Kedua (B) menjawab sama panjang. Setelah ditanyakan kembali: Mengapa? Diperoleh jawaban bahwa waktu digunting sama panjang. Jawaban yang diberikan menunjukkan bahwa dia melihat kodisi tali pada awalnya. Pertanyaan lanjutan hanya untuk melihat pemahan anak.

Dari jawaban tersebut, diketahui anak sudah memahami konsep kekekalan panjang. Kalau dilihat usia dari Didis yaitu 9 tahun 7 bulan, maka dia sudah berada pada tahapan berpikir operasi kongkrit berarti dia sudah dapat memahami konsep kekekalan panjang. Hal ini berarti bahwa ternyata ada anak yang sudah memahami konsep kekekalan panjang sesuai dengan tingkatan usianya yang berada pada tahapan berpikir kongkrit.

Untuk mengetahui lebih jauh tentang kedua anak tersebut, peneliti melakukan wawancara dengan kedua orang tuanya. Hasil wawancara dapat dilihat pada tabel berikut.

Tabel 1:

Kondisi kedua subjek penelitian

\begin{tabular}{|l|l|l|}
\hline \multicolumn{1}{|c|}{ Kondisi Anak } & \multicolumn{1}{c|}{ Subjek Pertama } & \multicolumn{1}{c|}{ Subjek kedua } \\
\hline Kondisi Kesehatan & Sering sakit & Jarang sakit \\
Sifat & Pendiam & Terbuka \\
Menyelesaikan PR & Sering dibantu & Kerjakan sendiri \\
Peringkat di kelas & 22 dari 34 & 7 dari 32 \\
\hline
\end{tabular}

\section{Kesimpulan dan Saran}

\section{A. Simpulan}

Berdasarkan pembahasan hasil penelitian, diketahui bahwa dari kedua anak tersebut yang merupakan subjek penelitian, hanya satu anak yang sudah memahami konsep kekekalan panjang. Jika dilihat usia kedua anak tersebut yaitu 8 tahun 6 bulan dan 9 tahun 7 bulan, seharusnya berdasarkan tahapan perkembangan piaget bahwa anak mulai memahami konsep kekekalan panjang pada usia 7 - 8 tahun. Sehingga dapat disimpulkan bahwa ada anak yang sesuai dengan usianya berada pada tahapan operasi kongkrit ternyata belum memahami konsep kekekalan panjang. 
Disisi yang lain, berdasarkan hasil wawancara dengan orang tua kedua anak tersebut, diperoleh data bahwa kedua anak tersebut memiliki perbedaan pada kondiri kesehatan, kebiasaan belajar, sifat, maupun peringkat dalam kelas. Pertanyaannya adalah apakah faktor-faktor ini berpengaruh? Hal ini dibutuhkan penelitian lanjutan.

\section{B. Saran}

Untuk guru, agar dalam mengajar dapat menyesuaikan dengan tahapan perkembangan anak, sehingga kemampuan siswa kita tidak kalah dengan kemampuan siswa diluar negeri. Untuk orang tua, agar selalu mengtrontrol belajar anak di rumah. Karena pendidikan juga merupakan tanggung jawab da orang tua.Untuk peneliti, penelitian ini dapat ditingkatkan pada tingkat leb. besar lagi. Baik tingkat sekolah, kabupaten, propinsi, bahkan secara nasional.

\section{Daftar Pustaka}

DePorter, Bobbi; Reardon, Mark; dan Nourie, Sarah Singer. (2000). Quantum Teaching: Mempraktikkan Quantum Learning di Ruang-ruang Kelas. Bandung: Kaifa.

Holil, Anwar. (2007) Model Pembelajaran Kooperatif. Tersedia: http://www.blogger.com /feeds/posts [16 Nopember 2011]

Hudojo Herman. (1988). Mengajar Belajar Matematika. Jakarta: Departemen Pendidakan dan Kebudayaan Direktorat Jenderal Pendidikan Tinggi Proyek Pengembangan LPTK.

Joko Sulianto Joko, (2010) Media dan Alat Peraga dalam Pembelajaran Matematika. Tersedia: http://www.infodiknas.com. (22 Nopember 2011)

Ruseffendi, E.T. (1990). Pengajaran Matematika Modern dan masa Kini untuk Guru dan PGSD D2 (Seri kedua). Bandung: Tarsito.

Ruseffendi, E.T. (2006). Pengantar kepada Membantu Guru Mengembangkan Kompetensinya dalam Pengajaran Matematika untuk Meningkatkan CBSA. Bandung: Tarsito.

Senduk, A.G. (1985). Teori Perkembangan Intelektual Jean Piaget. Bandung: FPS IKIP Bandung.

Soejadi. (2000). Kiat Pendidikan Matematika di Indonesia. Jakarta: Direktoran Jenderal Pendidikan Tinggi Departemen Pendidikan Nasional.

Sujono. (1988). Pengajaran Matematika untuk Sekolah Menengah. Jakarta: Departemen Pendidikan dan Kebudayaan

Suparno, P. (2003). Teori Perkembangan Kognitif Jean Piaget. Yogyakarta: Kanisius.

Wenger, W. (2004). Beyond Teaching \& Learning Memadukan Quantum Teaching \& Learning. Bandung: Nuansa. 